\title{
EPIDEMIOLOGY OF COMMUNITY-ACQUIRED SEPSIS IN ADULT PATIENTS: A SIX YEAR OBSERVATIONAL STUDY
}

\author{
Krsto Grozdanovski ${ }^{1}$, Zvonko Milenkovikj $^{1}$, Ilir Demiri ${ }^{1}$, Katerina Spasovska ${ }^{1}$, Marija Cvetanovska ${ }^{1}$, \\ Velimir Saveski ${ }^{1}$, Biljana Grozdanovska ${ }^{2}$ \\ ${ }^{1}$ University Clinic for Infectious Diseases, Medical Faculty, Skopje, Republic of Macedonia \\ ${ }^{2}$ University Clinic for Radiotherapy and Oncology, Medical Faculty, Skopje, Republic of Macedonia
}

Corresponding author: Krsto Grozdanovski, University Clinic for Infectious Diseases, Faculty of Medicine, University St. "Cyril and Methodius" - Skopje, Tel: 38970233 204; e-mail kgrozdanov@hotmail.com

\section{ABSTRACT}

Sepsis is defined as life-threatening organ dysfunction caused by a dysregulated host response to an infection and it is a major cause of morbidity and mortality worldwide. The aim of this study is to describe epidemiology of community-acquired sepsis in the Intensive care unit (ICU) of the Macedonian tertiary care University Clinic for Infectious Diseases. A prospective observational study was conducted over a 6-year period from January, 2011 to December, 2016. All consecutive adults with community-acquired sepsis or septic shock were included in the study. Variables measured were incidence of sepsis, age, gender, comorbidities, season, source of infection, complications, interventions, severity indexes, length of stay, laboratory findings, blood cultures, 28-day and in hospital mortality. Of 1348 admissions, 277 (20.5\%) had sepsis and septic shock. The most common chronic condition was heart failure (26.4\%), and the most frequent site of infection was the respiratory tract (57.4\%). Median Simplified Acute Physiology Score (SAPS II) was 50.0, and median Sequential Organ Failure Assessment (SOFA) score was 8.0. Blood cultures were positive in $22 \%$ of the cases. Gram-positive bacteria were isolated in $13 \%$ and Gram-negatives in $9.7 \%$ of patients with sepsis. The overall 28 -day and in hospital mortality was $50.5 \%$ and $56.3 \%$ respectively. The presence of chronic heart failure, occurrence of ARDS, septic shock and the winter period may influence an unfavorable outcome. Mortality compared to previous years is unchanged but patients that we have been treating these last 6 years have had more severe illnesses. Better adherence to the Surviving Sepsis guidelines will reduce mortality in this group of severely ill patients.

Keywords: sepsis, severe sepsis, septic shock, mortality, epidemiology

\section{INTRODUCTION}

Sepsis is defined as life-threatening organ dysfunction caused by a dysregulated host response to infection. [1] Despite considerable research, the incidence of affected patients has doubled and sepsis remains a major cause of morbidity and is the second leading cause of death worldwide. [2]

The incidence of sepsis varies across the world. The incidence of severe sepsis has been estimated at around 300 cases per 100,000 population in the United States. [3]

Depending on the place of acquisition, sepsis is defined as either a community or a hospital-acquired infection. It seems that the incidence of community-acquired sepsis is as high as $731 / 100.000$ persons per year. [4] 
In most developed countries, the incidence of sepsis has progressively increased [5] and the estimated cost per episode in the US is between $\$ 20,000$ and $\$ 50,000$; [6] Rising incidence and mortality from sepsis has promoted national and global efforts to improve awareness, early recognition, diagnosis, and treatment. The result was the Surviving Sepsis Campaign guidelines, and the implementation of these guidelines contributed to decreasing sepsis mortality. [7] However, mortality from sepsis remains higher than mortality of heart failure, breast cancer, colon cancer, and AIDS. [8]

Almost all knowledge regarding sepsis is from studies from developed countries. Epidemiological and clinical data from developing countries are very scarce; evidence suggests that mortality from sepsis is higher in Eastern Europe compared to Western Europe and Northern America. [6]

The aim of this study is to describe comorbidities, microbiologic profile, sources of infection, severity of illness and mortality of patients with community-acquired sepsis in the tertiary care hospital in the Republic of Macedonia.

\section{MATERIAL AND METHODS}

This prospective observational study was made over a 6-year period (from January 1, 2011 to December 31, 2016) in the Intensive Care Unit (ICU) of the University Clinic for Infectious Diseases in Skopje, Republic of Macedonia. The Clinic for Infectious Diseases is the only third level hospital for infectious diseases in the country covering 2 million inhabitants.

All consecutive adults (age $\geq 18$ years) with community-acquired sepsis or septic shock were included in the study. Sepsis was defined as infection and organ dysfunction measured with increase in the Sequential Organ Failure Assessment (SOFA) score of 2 points or more. Septic patients with persistent hypotension requiring vasopressors to maintain mean arterial pressure $\geq 65 \mathrm{~mm} \mathrm{Hg}$ and having serum lactate $>$ $2 \mathrm{mmol} / \mathrm{L}$ despite adequate volume resuscitation were defined as suffering from septic shock. [1]

Acute respiratory distress syndrome (ARDS) was defined based on the Berlin definition as ratio of partial pressure of arterial oxygen to fractional concentration of inspired oxygen
$\mathrm{PaO} 2 / \mathrm{FIO} 2 \leq 300$ and the presence of bilateral pulmonary opacities on chest radiograph not due exclusively to congestive heart failure or fluid overload. [10]

The inclusion of studied patients was before the publication of the Sepsis-3 definition, so the patients who did not meet new criteria were not included in the study. Patients who stayed in the ICU for less than $24 \mathrm{~h}$ were excluded. Informed consent was waived because the nature of this study was observational.

We recorded data on age, gender, comorbidities, site of infection, microbiological and laboratory data, season, SOFA score [11] and Simplified Acute Physiology Score (SAPS II. [12]

The main outcome measure of interest was 28-day mortality.

\section{Statistical Analysis}

Continuous variables were assessed for normality using the Kolmogorov-Smirnov test. Normally distributed variables are presented as mean and standard deviation, and non-normally distributed variables as median and interquartile range (IQR). Difference testing between groups was performed using the Student's t-test when data were normally distributed. When normality was rejected nonparametric Mann-Whitney U-test was used for independent groups. Categorical variables were expressed as numbers and percentages and analyzed using the chi-square and the Fisher exact test when necessary. All statistics were two-tailed, and a $\mathrm{p}<0.05$ was considered to be significant. Data were analyzed with SPSS 23.0 software (SPSS, Chicago, IL).

\section{RESULTS}

During the 6 year period, 19,892 patients were admitted to the University Clinic for Infectious Diseases, 1348 (6.78\%) of whom were treated in ICU. Among patients admitted in ICU, 328 were diagnosed with sepsis, 23 patients didn't meet the new Sepsis-3 definitions and 28 stayed less than 24 hours and were excluded from the study. A total of 277 patients met the inclusion criteria and were included in the analysis. Characteristics of patients stratified according to 28-day mortality are shown in Table 1. 
The median age of the included patients was 61 years (IQR: 46-71) years and $166(59.5 \%)$ of the cases were male. The most common comorbidities were heart failure $(26.4 \%)$, diabetes mellitus $(20.6 \%)$, and cerebrovascular disease $(16.2 \%)$. The median length of stay in ICU was 10 (IQR: 6-19) days, the duration of hospital stay was 14 (IQR: 8-23) days, and in both cases non-survivors had a significantly shorter stay. Sepsis was most frequently diagnosed in winter and mortality was significantly higher in cold months (Table 1).

Table 1. Characteristics of patients with sepsis according to outcome

\begin{tabular}{|c|c|c|c|c|}
\hline$\frac{0}{\frac{\pi}{\pi}}$ & 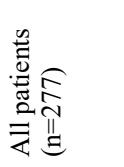 & 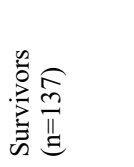 & 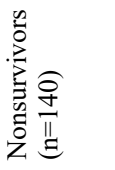 & $\begin{array}{c}\stackrel{0}{3} \\
\stackrel{\pi}{2} \\
0\end{array}$ \\
\hline Age, years (IQR) & $61(46-71)$ & $57(43-68)$ & $64(52-72)$ & 0.002 \\
\hline $\begin{array}{l}\text { Male, n (\%) } \\
\text { Female, n (\%) }\end{array}$ & $\begin{array}{l}166(59.5) \\
111(40.1)\end{array}$ & $\begin{array}{l}83(60.6) \\
54(39.4)\end{array}$ & $\begin{array}{l}83(59.3) \\
57(40.7)\end{array}$ & 0.902 \\
\hline ICU stay, days (IQR) & $10(6-19)$ & $17(9.5-28)$ & $8(5-11)$ & $<0.001$ \\
\hline Hospital stay, days (IQR) & $14(8-23)$ & $22(16-33)$ & $\begin{array}{l}8(5- \\
12.75)\end{array}$ & $<0.001$ \\
\hline $\begin{array}{l}\text { Comorbidities, } \mathrm{n}(\%) \\
\text { Congestive heart failure } \\
\text { Diabetes mellitus } \\
\text { Cerebrovascular disease } \\
\text { COPD } \\
\text { Chronic alcoholism } \\
\text { Metastatic cancer } \\
\text { Chronic kidney disease } \\
\text { Chronic liver disease } \\
\text { AIDS/HIV infection }\end{array}$ & $\begin{array}{l}73(26.4) \\
57(20.6) \\
45(16.2) \\
25(9.0) \\
13(4.7) \\
24(8.7) \\
19(6.9) \\
10(3.6) \\
4(1.4)\end{array}$ & $\begin{array}{l}21(15.3) \\
25(18.2) \\
28(20.4) \\
8(5.8) \\
6(4.4) \\
13(9.5) \\
6(4.4) \\
1(0.7) \\
3(2.2)\end{array}$ & $\begin{array}{l}52(37.1) \\
32(22.9) \\
17(12.1) \\
17(12.1) \\
7(5.0) \\
11(7.9) \\
13(9.3) \\
9(6.4) \\
1(0.7)\end{array}$ & $\begin{array}{l}<0.001 \\
0.343 \\
0.061 \\
0.067 \\
0.807 \\
0.629 \\
0.106 \\
0.011 \mathrm{ex} \\
0.367 \mathrm{ex}\end{array}$ \\
\hline $\begin{array}{l}\text { Season, n (\%) } \\
\text { Spring } \\
\text { Summer } \\
\text { Autumn } \\
\text { Winter }\end{array}$ & $\begin{array}{l}70(25.3) \\
49(17.7) \\
62(22.4) \\
96(34.7)\end{array}$ & $\begin{array}{l}36(26.3) \\
26(19.0) \\
37(27.0) \\
38(27.7)\end{array}$ & $\begin{array}{l}34(24.3) \\
23(16.4) \\
25(17.9) \\
58(41.4)\end{array}$ & $\begin{array}{l}0.782 \\
0.638 \\
0.068 \\
0.017\end{array}$ \\
\hline Septic shock, n (\%) & $82(29.6)$ & $20(14.6)$ & $62(44.3)$ & $<0.001$ \\
\hline ARDS, n (\%) & $61(22)$ & $23(16.8)$ & $38(27.1)$ & 0.038 \\
\hline $\begin{array}{l}\text { Mechanical ventilation, } \\
\mathrm{n}(\%)\end{array}$ & $170(61.4)$ & $55(40.1)$ & $\begin{array}{l}115 \\
(82.1)\end{array}$ & $<0.001$ \\
\hline $\begin{array}{l}\text { Length of ventilation } \\
\text { (days), median (IQR) }\end{array}$ & $7(4-12)$ & $13(7-26)$ & $6(3-9)$ & $<0.001$ \\
\hline RRT, n (\%) & $44(15.9)$ & $18(13.1)$ & $26(18.7)$ & 0.207 \\
\hline $\begin{array}{l}\text { SOFA score, median } \\
\text { (IQR) }\end{array}$ & $\begin{array}{l}8.0(6.0- \\
10.0)\end{array}$ & $\begin{array}{l}6.0(5.0- \\
8.0)\end{array}$ & $\begin{array}{l}9.0(7.0- \\
11.75)\end{array}$ & $<0.001$ \\
\hline $\begin{array}{l}\text { SAPS II score, median } \\
\text { (IQR) }\end{array}$ & $\begin{array}{l}50.0 \\
(40.0- \\
62.0)\end{array}$ & $\begin{array}{l}42.0(32.5- \\
53.0)\end{array}$ & $\begin{array}{l}56.5 \\
(47.0- \\
68.0)\end{array}$ & $<0.001$ \\
\hline
\end{tabular}

IQR, interquartile range; ARDS, acute respiratory distress syndrome; RRT, renal replacement therapy; SOFA, sequential organ failure assessment; SAPS II, simplified acute physiology score II;

Septic shock and consequently administration of vasopressors was noted in $82(29.6 \%)$ patients, acute respiratory distress syndrome (ARDS) was diagnosed in $61(22 \%)$, mechanical ventilation was utilized in $170(61.4 \%)$ and renal replacement therapy in $44(15.9 \%)$ patients. Median SAPS II score during the first $24 \mathrm{~h}$ was 50 (IQR: 40-62) and the SOFA score was 8.0 (IQR: 6-10), and both were significantly higher in non-survivors. White blood cells and concentration of urea in the blood were significantly higher in patients who died. Levels of plasma albumin were significantly lower in non-survivors (Table 2).

Table 2. Laboratory Characteristics of patients with sepsis

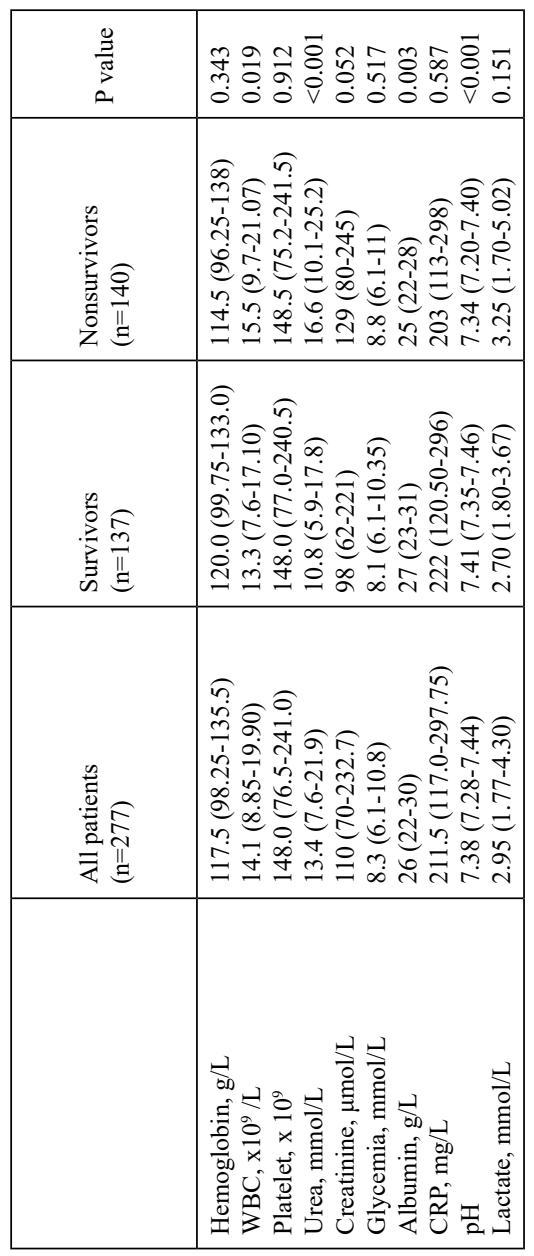

Data are presented as median (IQR)

Standardized Mortality Ratio (SMR) was calculated by dividing the observed mortality rate by the predicted mortality rate with SAPS II. In this cohort SMR was 1.08.

The most common sources of infection were: respiratory tract $(57.4 \%)$, central nervous system $(18.4 \%)$, soft tissue $(8.7 \%)$, and no primary infectious site were associated with mortal- 
ity (Table 3). Microorganisms were isolated from blood cultures in $63(22.7 \%)$ patients. Gram-positive bacteria were isolated from $36(57.1 \%)$ and Gram-negative bacteria from $27(42.9 \%)$ patients. Staphylococcus aureus and Escherichia coli were the most frequently isolated pathogens (Table 4).

Table 3. The Source of infection in sepsis patients

\begin{tabular}{|l|l|l|l|l|}
\hline $\begin{array}{l}\text { Site of infection, } \\
\mathrm{n}(\%)\end{array}$ & $\begin{array}{l}\text { All patients } \\
(\mathrm{n}=277)\end{array}$ & $\begin{array}{l}\text { Survivors } \\
(\mathrm{n}=137)\end{array}$ & $\begin{array}{l}\text { Nonsurvivors } \\
(\mathrm{n}=140)\end{array}$ & P value \\
\hline Respiratory & $159(57.4)$ & $76(55.5)$ & $83(59.3)$ & 0.521 \\
CNS & $51(18.4)$ & $27(19.7)$ & $24(17.1)$ & 0.582 \\
Soft tissue & $24(8.7)$ & $14(10.2)$ & $10(7.1)$ & 0.363 \\
Urinary & $15(5.4)$ & $11(8.0)$ & $4(2.9)$ & 0.057 \\
Abdominal & $9(3.2)$ & $2(1.5)$ & $7(3.2)$ & 0.173 \\
Endocarditis & $7(2.5)$ & $5(3.6)$ & $2(1.4)$ & 0.278 \\
Other/Unknown & $15(5.4)$ & $7(5.1)$ & $8(5.7)$ & 0.824 \\
\hline
\end{tabular}

Table 4. Microorganisms isolated from blood cultures in patients with sepsis

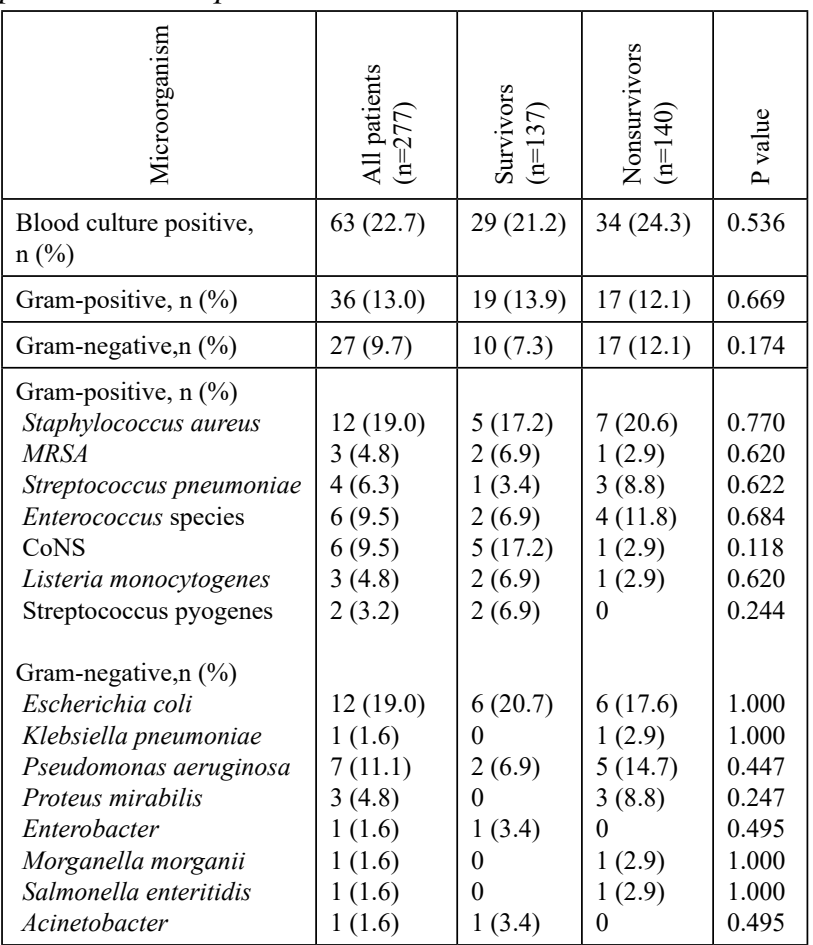

MRSA, Methicillin-resistant Staphylococcus aureus, CoNS, coagulase-negative staphylococci

The overall 28 -day mortality was $50.5 \%$ and in hospital mortality $56.3 \%$ (Table 5).

Table 5. Mortality in patients with sepsis

\begin{tabular}{|l|l|l|l|}
\hline & Overall & Sepsis & Septic shock \\
\hline 28-day (\%) & 50.5 & 40 & 75.6 \\
\hline Hospital (\%) & 56.3 & 46.2 & 80.5 \\
\hline
\end{tabular}

\section{DISCUSSION}

This is a single-center, observational study aiming to investigate the epidemiological characteristics and clinical outcomes of patients with community-acquired sepsis. In Macedonia, within the University Clinical Centre in Skopje, apart from the surgical and coronary intensive care unit, only our intensive care unit provides mechanical ventilation, hemodialysis and hemodynamic monitoring for adult patients with infectious and sometimes non-infectious diseases.

In this study, we used sepsis-3 definitions which overlapped with sepsis-2 definitions in $92 \%$ of cases, similar to other reports [13]. The reason for excluding 23 patients was mostly because we didn't have a lactate measurement.

The incidence rate of patients with sepsis treated in ICU was $20.5 \%$. The reported incidence varies from as low as $4.7 \%$ to $37.3 \%$ $[14,15,16,17]$. Incidence of sepsis is related to the differences in ICU types like medical, surgical or mixed. Moreover, different inclusion criteria may also explain the reported discrepancy.

Older age was clearly associated with worse prognosis $(p=0.002)$. Elderly septic patients often do not have typical clinical responses to sepsis such as fever, tachycardia and hypoxemia and sepsis may present with hypothermia, leukopenia or nonspecific signs of infection. [18] As a result of variable manifestations of infection in the elderly, the diagnosis of sepsis is often delayed.

The majority of patients had some chronic condition which emphasizes the importance of appropriate management of comorbidities and prevention strategies like pneumococcal and influenza vaccination.

In this study, we find that sepsis is more common in the winter season and when the mortality is also higher. The reason for this seasonal variation is the prevalence of viral respiratory and bacterial infections in the colder months of the year. [19] In contrast to other studies, we found higher incidence of ARDS in septic patients [22\%] but the mortality of $62.3 \%$ was similar to other publications [20, 21]. In all patients with ARDS low tidal volume ventilation was used. [22] 
The median score of SAPS-II of the subjects in this study was 50.0 and the predicted mortality rate for SAPS II was $46.0 \%$. But the actual mortality rate was $50.5 \%$. Thus, SAPS II under-predicted mortality of the study subjects, gave a Standardized Mortality Rate (SMR) of 1.08. A study conducted in India found SMR of 1.40 [23] and a more recent publication presented SMR of 0.80 [24]. Even though SMR of 1.08 does not represent many "excess deaths" in the study population, our goal is SMR well under 1.0.

Hypoalbuminemia was common in our patients with sepsis and was significantly lower in patients who did not survive. Albumin is frequently decreased in the acute phase of sepsis, and its levels are reduced by approximately 10-15 g/L within 1 week of the event. Serum albumin has protective effects such as maintaining physiologic homeostasis, antioxidant activity, anti-inflammatory effects, and prevention of apoptosis. [25] These protective functions may be impaired in hypoalbuminemic conditions, and increased morbidity and mortality can consequently develop in patients with sepsis. [26, 27]

During the first day of treatment, the plasma concentration of CRP was high (median 211 $\mathrm{mg} / \mathrm{L}$ ). A high CRP levels correlate with disease severity and may represent the effectiveness of an antimicrobial therapy but CRP usefulness for outcome prediction and discrimination between infectious and non-infectious processes is questionable. [28]

In more than $50 \%$ of the patients, the respiratory tract was the principal site of infection but with no influence on outcome, in accordance with many epidemiological studies on sepsis. [3, 29, 30]

In the present work, blood cultures were positive in $22.7 \%$ of septic patients, with slight predominance of Gram-positives. In general, the positivity of blood cultures can vary from $12.5 \%$ to no more than $40 \%$ even in cases with septic shock $[31,32,33,34]$. There are many explanations why the yield of blood cultures in septic patients is so low. In many cases there is nothing to cultivate to blood cultures because local infections stimulate powerful pro- and anti-inflammatory mediators responsible for organ dysfunction without any invasion of microorganisms in the blood stream. Secondly, patients may have received antibiotics prior to the onset of organ dysfunction, thus obscuring conventional cultures. Thirdly, the diag- nostic workup may be inadequate, blood drawn after administration of antibiotics, not enough blood or contamination of blood culture bottles. A fourth possible explanation is sepsis caused by unusual organisms that are difficult to identify in routine practice. [35]

The 28-day overall mortality was 50.5\%. The mortality in patients with sepsis was $40 \%$ and $75.6 \%$ mortality in patients with septic shock. These are similar finding to our previous report except that in this cohort SAPS II score was much higher implicating the higher severity of illness. [36] These mortality rates are higher than reported from developed European countries like Germany where mortality from sepsis is $43.6 \%$ and $58.8 \%$ from septic shock. [37] Adherence to the Surviving Sepsis Campaign guidelines in the USA contributes to sepsis mortality reduction to up to 50\%. [38] The cornerstone of sepsis therapy and the key for reducing mortality is early recognition, aggressive fluid therapy and early administration of antimicrobials. [39, 40]

In our opinion, in order to reduce the mortality rates of septic patients we should improve adherence to the Surviving Sepsis Campaign bundles with early diagnosis, routine lactate measurement, adequate fluid resuscitation with defined endpoints, and satisfactory support of the cardiac output when depressed. We think that our adherence to sepsis guidelines about antibiotics, mechanical ventilation, renal replacement therapy, management of hyperglycemia, and use of corticosteroids, are appropriate.

\section{CONCLUSION}

The present study shows that community-acquired sepsis and septic shock are common events in ICU. Predominant source of infection was the respiratory tract, and Gram positive bacteria were the major causative microorganisms. The presence of chronic heart failure, occurrence of ARDS, septic shock, and the winter period may influence anunfavorable outcome. Mortality, compared to previous years, is unchanged but patients that we have been treating these last 6 years have had more severe illnesses. Better adherence to Surviving Sepsis Guidelines will reduce mortality in this group of severely ill patients. 


\section{REFERENCES}

1. Singer M, Deutschman C, Seymour C, et al. The third international consensus definitions for sepsis and septic shock (sepsis-3). JAMA 2016; 315: 801-10.

2. Linde-Zwirble WT, Angus DC. Severe sepsis epidemiology: Sampling, selection, and society. Crit Care 2004; 8: 222-6.

3. Angus DC, Linde-Zwirble WT, Lidicker J, et al. Epidemiology of severe sepsis in the United States: analysis of incidence, outcome, and associated costs of care. Critical care medicine 2001; 29(7): 1303-1310.

4. Henriksen DP, Laursen CB, Jensen TG, et al Incidence Rate of Community-Acquired Sepsis Among Hospitalized Acute Medical Patients - A Population-Based Survey. Crit Care Med 2015; 43: 13-21.

5. Mayr FB, Yende S, Angus DC. Epidemiology of severe sepsis. Virulence 2014; 5(1): 4-11.

6. Moerer O, Plock E, Mgbor U, et al. A German national prevalence study on the cost of intensive care: an evaluation from 51 intensive care units. Crit Care 2007; 11(3): R69.

7. Martin GS. Sepsis, severe sepsis and septic shock: changes in incidence, pathogens and outcomes. Expert Rev Anti-Infect Ther 2012; 10(6): 701-6.

8. Ferrer R, Artigas A, Levy MM, et al. Improvement in process of care and outcome after a multicenter severe sepsis educational program in Spain. JAMA 2008; 299(19): 2294-303.

9. Vincent JL, Rello J, Marshall J, et al. International study of the prevalence and outcomes in infection in intensive care units. JAMA 2009; 302: 2323-9.

10. Ranieri VM, Rubenfeld GD, Thompson BT, et al. ARDS Definition Task Force. Acute respiratory distress syndrome: the Berlin definition. JAMA 2012; 307: 2526-2533.

11. Vincent JL, Moreno R, Takala J, et al. The SOFA (Sepsis-related Organ Failure Assessment) score to describe organ dysfunction/failure. On behalf of the Working Group on Sepsis-Related Problems of the European Society of Intensive Care Medicine. Intensive Care Med 1996; 22(7): 707-10.

12. Le Gall JR, Lemeshow S, Saulnier F. A new Simplified Acute Physiology Score (SAPS II) based on a European/North American multicenter study. JAMA 1993; 270: 2957-2963.
13. Shankar-Hari M, Harrison DA, Rubenfeld GD, Rowan K. Epidemiology of sepsis and septic shock in critical care units: comparison between sepsis-2 and sepsis-3 populations using a national critical care database. Br J Anaesth 2017; 119(4): 626-636.

14. Ogura H, Gando S, Saitoh D, et al. Epidemiology of severe sepsis in Japanese intensive care units: a prospective multicenter study. J Infect Chemother 2014; 20: 157-162.

15. Brun-Buisson C, Meshaka P, Pinton P, et al. EPISEPSIS: a reappraisal of the epidemiology and outcome of severe sepsis in French intensive care units. Intensive Care Med 2004; 30: 580-588.

16. Padkin A, Goldfrad C, Brady AR, et al. Epidemiology of severe sepsis occurring in the first $24 \mathrm{hrs}$ in intensive care units in England, Wales, and Northern Ireland. Crit Care Med 2003; 31: 2332-2338.

17. J. Zhou, C. Qian, M. Zhao, et al. Epidemiology and outcome of severe sepsis and septic shock in intensive care units in mainland China. PLoS One 2014; 9(9); p. e107181.

18. Warmerdam M, Stolwijk F, Boogert A, et al. Initial disease severity and quality of care of emergency department sepsis patients who are older or younger than 70 years of age. PLoS One 2017; 12(9): e0185214.

19. Danai PA, Sinha S, Moss M, et al. Seasonal variation in the epidemiology of sepsis. Critical care medicine 2007; 35(2): 410-415.

20. Mikkelsen ME, Shah CV, Meyer NJ, et al. The epidemiology of acute respiratory distress syndrome in patients presenting to the emergency department with severe sepsis. Shock Augusta Ga 2013; 40(5): 375-381.

21. Kim W-Y, Hong S-B. Sepsis and Acute Respiratory Distress Syndrome: Recent Update. Tuberc Respir Dis (Seoul) 2016; 79(2): 53-7.

22. ARDSnet Investigators. Ventilation with lower tidal volumes as compared with traditional tidal volumes for acute lung injury and the acute respiratory distress syndrome. N Engl J Med 2000; 342: 1301-8.

23. Todi S, Chatterjee S, Bhattacharyya M. Epidemiology of severe sepsis in India. Crit Care 2007; 11(Suppl 2): 65.

24. Dabhi AS, Khedekar SS, Mehalingam V. A Prospective Study of Comparison of APACHE-IV $\&$ SAPS-II Scoring Systems and Calculation of Standardised Mortality Rate in Severe Sepsis and Septic Shock Patients. Journal of Clinical and 
Diagnostic Research : JCDR 2014;8(10):MC09MC13.

25. Lee JH, Kim J, Kim K, et al. Albumin and C-reactive protein have prognostic significance in patients with community-acquired pneumonia. J Crit Care 2011; 26: 287-94.

26. Artero A, Zaragoza R, Camarena JJ, et al. Prognostic factors of mortality in patients with community-acquired bloodstream infection with severe sepsis and septic shock. J Crit Care 2010; 25: 276-81.

27. Seo MH, Choa M, You JS, et al. Hypoalbuminemia, Low Base Excess Values, and Tachypnea Predict 28-Day Mortality in Severe Sepsis and Septic Shock Patients in the Emergency Department. Yonsei Medical Journal 2016; 57(6): 13611369.

28. Kojic D, Siegler BH, Uhle F, et al. Are there new approaches for diagnosis, therapy guidance and outcome prediction of sepsis? World J Exp Med 2015; 5(2): 50-63.

29. Ogura H, Gando S, Saitoh D, et al. Epidemiology of severe sepsis in Japanese intensive care units: a prospective multicenter study. J Infect Chemother 2014; 20: 157-162.

30. Kempker JA, Martin GS. The changing epidemiology and definitions of sepsis. Clin Chest Med 2016; 37: 165-79.

31. Bouza C, Lopez-Cuadrado T, Saz-Parkinson Z, et al. Epidemiology and recent trends of severe sepsis in Spain: a nationwide population-based analysis (2006-2011) BMC Infect Dis 2014; 14: 3863.

32. Baharoon S, Telmesani A, Tamim H, et al. Community- versus nosocomial-acquired severe sepsis and septic shock in patients admitted to a tertiary intensive care in Saudi Arabia, etiology and outcome. J Infect Public Health 2015; 8(5): 418-24.

33. Seymour CW, Gesten F, Prescott HC, et al. Time to treatment and mortality during mandated emergency care for sepsis. N Engl J Med 2017; 376(23): 2235-2244.

34. Angus DC, van der Poll T: Severe sepsis and septic shock. N Engl J Med 2013; 369: 2063.

35. De Prost N, Razazi K, Brun-Buisson C. Unrevealing culture-negative severe sepsis. Critical Care. 2013; 17(5): 1001.

36. Grozdanovski K, Milenkovic Z, Demiri I, et al. Prediction of outcome from community-acquired severe sepsis and septic shock in tertiary-care university hospital in a developing country. Critical care research and practice 2012; 2012: 182324.

37. Fleischmann C, Thomas-Rueddel DO, et al. Hospital Incidence and Mortality Rates of Sepsis. Dtsch Arztebl Int 2016; 113(10): 159-66.

38. Rhodes A, Evans LE, Alhazzani W, et al. Surviving Sepsis campaign: international guidelines for Management of Sepsis and Septic Shock: 2016. Intensive Care Med 2017; 43: 304-377.

39. Pro CI, Yealy DM, Kellum JA, et al. A randomized trial of protocol-based care for early septic shock. N Engl J Med 2014; 370(18): 1683-93.

40. The ARISE Investigators. the ANZICS Clinical Trial Group. Peake SL, Delaney A, Bailey M, et al. Goal-directed resuscitation for patients with early septic shock. N Eng1 J Med 2014; 371(16): 1496-1506. 


\title{
Резиме
}

\section{ЕПИДЕМИОЛОШКИ КАРАКТЕРИСТИКИ НА СЕПСА СТЕКНАТА ВО ЗАЕДНИЦАТА КАЈ АДУЛТИ: ШЕСТГОДИШНА ОПСЕРВАЦИСКА СТУДИЈА}

\author{
Крсто Гроздановски ${ }^{1}$, Звонко Миленковиќ ${ }^{1}$, Илир Демири $^{1}$, Катерина Спасовска $^{1}$, \\ Марија Цветановска ${ }^{1}$, Велимир Савески ${ }^{1}$, Биљана Гроздановска ${ }^{2}$ \\ ${ }^{1}$ Универзитетска клиника за инфективни болести, Медицински факултет, \\ Скопје, Република Македонија \\ 2 Универзитетска клиника за радиотерапија и онкологија, Медицински факултет, \\ Скопје, Република Македонија
}

Сепсата претставува животозагрозувачка дисфункција на органите, предизвикана од нерегулиран одговор на домаќинот кон инфекцијата и е главна причина за морбидитет и морталитет во целиот свет. Целта на студијата е да се опише епидемиологијата на сепса стекната во заедницата во Единицата за интензивна нега на Универзитетската клиника за инфективни болести. Проспективната опсервациска студија беше спроведена во текот на шестгодишен период - од јануари 2011 до декември 2016 година. Беа вклучени сите возрасни пациенти со вонболнички стекната сепса или септичен шок. Мерени беа следниве варијабли: инциденција, возраст, пол, коморбидитети, сезона, компликации, интервенции, индекси на тежина, должина на престој, лабораториски наоди, извор на инфекција, хемокултури, 28-дневен и болнички морталитет. Од 1348 примени пациенти, 277 $(20,5 \%)$ имаа сепса и септичен шок. Најчеста хронична состојба беше срцевата слабост $(26,4 \%)$, а најчеста локализација на инфекцијата беше респираторниот тракт $(57,4 \%)$. Медијаната на SAPS II индексот беше 50, а медијаната на СОФА-индексот изнесуваше 8. Хемокултурите беа позитивни кај $22 \%$ од случаите. Грам-позитивни бактерии беа изолирани во $13 \%$ и Грам-негативи кај 9,7\% од пациентите. 28-дневниот и болничкиот морталитет изнесуваa 50,5\%, односно 56,3\%. Предоминантен извор на инфекција кај пациентите со сепса е респираторниот тракт, а Грам-позитивните бактерии се најчестите предизвикувачи. Присуството на хронична срцева слабост, ARDS, септичен шок и зимскиот период можат да влијаат за неповолен исход. Смртноста во споредба со претходните години не е променета, но пациентите што ги третиравме последните шест години имаа потешка болест. Подоброто придржување кон упатствата за преживување од сепса ќе ја намали смртноста кај оваа група тешко болни пациенти.

Клучни зборови: сепса, тешка сепса, септичен шок, морталитет, епидемиологија 